\title{
EFFECT OF SOME FEED ADDITIVES ON REARING CALVES FROM BIRTH TILL WEANING: 1- PRODUCTIVE PERFORMANCE AND SOME BLOOD PARAMETERS
}

Talha, M. H.; R. I. Moawd; A. A. Abu El-Ella and G. H. Zaza. Animal Production Research Institute, Agric. Research Center, Egypt. \begin{abstract}
Eighteen suckling buffalo calves were divided depending on weight and sex into three similar experimental treatments (4 males and 2 females per each) to study the effect of mannan oligosaccarides (MOS) or commercial probiotic supplementation on performance, some blood constituents and economic efficiency of suckling buffalo calves. The calves of the $1^{\text {st }}$ treatment $(\mathrm{R} 1)$ were fed a basal ration consisting of whole milk, starter and berseem hay. The calves of the $2^{\text {nd }}(R 2)$ and $3^{\text {rd }}$ treatments (R3) were fed a basal ration supplemented with either $6 \mathrm{gm}$ probiotic or $4 \mathrm{gm} \mathrm{MOS}$ per calf per day, respectively. Supplementations were mixed with whole milk once a day during morning suckling. Calves were individually fed milk from $3^{\text {rd }}$ days old, while solid feeds (starter and berseem hay) were fed ad libitum in groups starting from $2^{\text {nd }}$ week of age up to weaning at $15^{\text {th }}$ weeks of age. Water was available free choice. Feed intake was measured daily, cases of diarrhea or any other diseases were recorded. Animal body weights were recorded biweekly. Three digestibility trials were carried out at $10^{\text {th }}$ week old to evaluate the tested treatments. Blood sampling were conducted at days 35,70 and 105 .
\end{abstract}

The results obtained were:

- The best digestibilties of various nutrients were recorded with calves fed R3 followed by those fed R2.

- $\quad$ Calves fed R3 had the highest values of average daily feed intake expressed as $\mathrm{DM}, \mathrm{TDN}$ and DCP, while calves fed $\mathrm{R} 1$ recorded the lowest intake.

- The averages of daily body gain were $0.660 ; 0.722$ and $0.779 \mathrm{~kg} / \mathrm{head} / \mathrm{day}$ for calves fed R1, R2 and R3, respectively.

- The MOS and probiotic supplementation for claves induced increases in serum concentrations of total protein, albumin, globulin, AST, total lipids, glucose, Zn and Fe than control calves. However, depressions in serum concentrations of $\mathrm{ALT}$, cholesterol, triglycerides, and urea- $\mathrm{N}$ were detected.

- There were significant $(P<0.05)$ differences in serum total protein, albumin, AST, ALT, total lipids, cholesterol , glucose, urea-N, Zinc and Fe concentrations among the age of claves.

- Calves fed R3 had the best feed conversion as $\mathrm{kg} \mathrm{DM}$, TDN and DCP/ $\mathrm{kg}$ gain, while calves fed R1 showed the poorest feed conversion.

- $\quad$ Calves fed ration supplemented with MOS and probiotic recorded lowest diarrhea cases.

- Less daily cost/ kg gain was recorded for calves fed either R2 or R3, while the highest expensive $\mathrm{kg}$ gain cost was with those fed R1.

It can be concluded that, supplementing milk of suckling buffalo calves with mannan oligosaccarides (MOS) or commercial probiotic product enhance feed intak, body weight gain, feed conversion, some blood parameters and rearing economic efficiency, with a higher superiority of MOS results.

Keywords: Suckling buffalo calves, mannan oligosaccarides, probiotic, body weight gain, performance, glucose, hormones 
Talha, M. H. et al.

\section{INTRODUCTION}

Prior to weaning young calves are susceptible to many pathogens that cause diseases. Over $75 \%$ of death in calves occur during the first month of neonatal life (Sampath, 1989). In Egypt, enteritis and diarrhea appear to be the most serious diseases among newly born calves (Fadl Allah, 1996). The studies on neonatal buffalo calves revealed a remarkable increase of the incidence of diarrhea reaching $67 \%$ with a mortality rate of $10.78 \%(\mathrm{El}$ Garhy et al., 1994).

The use of antibiotics in feed of young calves has been a common practice in animal production to improve feed efficiency and to decrease incidence of scours and calf mortality (Rusoff et al., 1959). However, over use of antibiotics exerts selective pressure that renders antibiotics ineffective (Amabile - Cuevas et al., 1995). Several additives have been proposed to improve calf health as alternative to the use of antibiotics as growth promoters. Some of these include mannan oligosaccharides (Jacqus and Newman, 1994; Heinrichs et al., 2003 and Terre et al., 2007) and probiotic (Malik et al., 1998; Gaafar et al., 2005 and Kamra and Pathak, 2005).

Mannan oligosaccharides (MOS) derived from yeast cell wall material have been found useful as means supplying complex carbohydrates with nutritional and immunological roles in the young animals (Dildey et al., 1997). Dvorak et al. (1997) reported that adding complex carbohydrates to a calf's diet may improve performance and health. The hypothesized mode of action is through: 1) blocking of pathogenic bacteria colonization in the gut, and 2) absorbing of pathogen - produced toxins. The goals of MOS supplementation include the optimization of intestinal microflora composition, increasing the nutrients absorption, prevention of intestinal disorder and achievement of better performance results (Kumprechtova and Lllek, 2007). Moreover, Heinrichs et al. (2003) reported that addition of $4 \mathrm{~g} \mathrm{MOS}$ per calf daily to milk replacer appeared to benefit calf health and reduced scours, indicating that MOS could effectively replace antibiotics in milk replacer.

Probiotics are a live microbial feed supplement that beneficially affects the host animal by improving its intestinal microbial balance (Fuller, 1989). Moreover, many of the beneficial productive responses associated with the use of probiotics associated with the use of probiotics supplements can be directly related to their effects on the microbial population in the digestive tract (McCormick, 1984; Nahshon et al., 1992 and Dawson, 1995). Probiotics decrease digestive disturbances and improve feed conversion and health performance (Windschitl, 1992). The nutritional effect of probiotics is characterized by an improvement of the utilization of nutrients by the host. This effect can be monitored by digestibility measurements (Roberton and Chevalier, 1997). The administration of bacteria used as a probiotic to young animals would be of great usefulness probably because its antigenic stimulation would favour the maturation of the secretory immune system thus preventing infection (Perdigon and Alvarez, 1992). Oral inculcation of animal with lactobacilli led to elevated levels of total serum proteins, globulin and increased white blood cells count (Pollmann et al., 1980). Therefore, the 
present study was carried out to investigate the effect of mannan oligosaccharides (MOS) and commercial probiotic product supplementation on performance, some blood constituents and economical efficiency of suckling buffalo calves.

\section{MATERIALS AND METHODS}

This study was carried out at El-Gemmeza Animal Production Research Station, Animal Production Research Institute, Agricultural Research Center, to investigate the effect of mannan oligosaccharides (MOS) and commercial probiotic product supplementation on performance, some blood constituents and economical efficiency of suckling buffalo calves.

A total of 18 newly born buffalo calves (12 males and 6 females) were used in this study. Animals were distributed according to their body weights and sex to 3 experimental treatments, each treatment consisted of 6 calves (4 males and 2 females). In the control (R1), animals were fed the basal ration consisted of whole milk, starter and berseem hay. While, in the second treatment (R2) animals were fed the basal ration plus a supplement of $6 \mathrm{~g}$ commercial probiotic product/ calf/ day as recommended by the producer in the whole milk once daily during the morning suckling. Commercial probiotic product is a natural product which contains fermented soybean meal with a culture of lactic acid bacteria with a bacteria count of $10^{8} \mathrm{CFU} / \mathrm{ml}$ as well as fermented grass from pastures rich in herbs, horseradish and fermented oak bark shavings. Meanwhile, in the third treatment (R3) animals were fed the basal ration plus a supplement of $4 \mathrm{~g}$ MOS (Bio-Mos)/ calf/ day/ as recommended by Terre et al., (2007) in the whole milk once daily during the morning suckling. Bio-Mos is a natural product derived from the outer cell wall of a specific strain of saccharomyces cerevisiae. The product contains mannan, glucan, protein and various other components found in the yeast cell wall (100\% purity) as mentioned by Terre et al. (2007). Calves were used directly after the colostrum feeding period at three days of age up to weaning ( 15 weeks old). Calves were individually suckled milk by bucket twice daily at $8.00 \mathrm{am}$ and at $4.00 \mathrm{pm}$, while dry feeds (starter and berseem hay)were group fed ad lib., starting from $2^{\text {nd }}$ weeks of age up to weaning at $15^{\text {th }}$ weeks of age. Feed residuals, if any were weighed and amounts consumed were recorded daily for each group. Clean water was available in free amount. Vitamins and minerals mixture blocks were provided freely. Health condition of calves were supervised over entire experimental period and cases of diarrhea or any other diseases were recorded. Calves were fed according to the recommended requirements of Animal Production Research Institute (1997). Individual live body weight (LBW) was recorded every two weeks and then total and average daily gain (ADG) were calculated. Starter composition was $43 \%$ yellow corn, $25 \%$ wheat bran; $15 \%$ Soybean meal; $10 \%$ linseed meal; $4 \%$ molasses, $2 \%$ limestone and $1 \%$ common salt.

Blood samples were collected by jugular vein puncture in clean test tubes from all experimental calves in the morning before feeding and drinking at $35^{\text {th }}, 70^{\text {th }}$ and $105^{\text {th }}$ day age. The samples were left to clot for $24 \mathrm{hr}$ in 
refrigerator and centrifuged at $4000 \mathrm{rpm}$ for 15 minutes. Blood serum was carefully separated and stored at $-20^{\circ} \mathrm{C}$ for determination of total proteins (TP), albumin, globulin, albumin/ globulin ratio (A/ G ratio), aspartate amino transferase (AST), alanine amino transferase (ALT), cholesterol, triglycerides, Glucose, $\mathrm{Zn}$ and Fe. Total proteins and albumin were determined according to Doumas and Biggs (1972 a \&b), globuline was calculated by subtraction concentration of albumin from the corresponding total protein then albumin/ globulin ratio (A/ G ratio) was also calculated. AST and ALT activities were determined as described by Reitman and Frankel (1957). Commercial kits were used for calorimetric determination of serum total cholesterol, triglycerides and serum glucose. Urea nitrogen concentration was determined according to Talk and Schubert (1965) and creatinine concentration according to Bartels (1971). Concentration of $\mathrm{Fe}$ and $\mathrm{Zn}$ in serum were determined by the absorption spectrophotometer.

During the experimental period in weeks $8-10$, three digestibility trials were carried out using 3 calves in each group to determine the digestion coefficients of experimental diets. Each digestibility trial consisted of 14 days preliminary period, followed by 7 days of fecal collection. Fecal grape samples were taken from the rectum three time daily during the collection period. Acid insoluble ash (AIA) was used as natural marker for nutrients digestibility determination (Van Keulen and Young, 1977). Representative samples of starter, berseem hay and feces were analyzed according to $A$. $O$. A. C. (1990). Whole milk samples were analyzed using milko -Scan (133 B. Foss Electronic).

The data was subjected to statistical analysis using general linear model procedure adapted by SPSS (1999) for user's guide with one - way ANOVA. Also, Duncan's test within program of SPSS was done to determine the degree of significance between the means.

\section{RESULTS AND DISCUSSION}

\section{Chemical composition:}

Chemical composition of feed ingredients is shown in Table (1). Chemical composition of buffalo milk, starter and berseem hay were within the range obtained by El - Ashry et al. (2003) and Matter et al. (2005).

Table (1): Chemical composition (on DM basis) and nutritive values of whole milk and experimental feedstuffs.

\begin{tabular}{|l|c|c|c|c|c|c|c|c|c|}
\hline \multirow{2}{*}{ Items } & \multirow{2}{*}{ DM \% } & \multicolumn{9}{|c|}{ Chemical composition, DM basis \% } & \multicolumn{3}{c|}{ Nutritive values\%* } \\
\cline { 3 - 9 } & & OM & CP & CF & EE & NFE & Ash & TDN & DCP \\
\hline Buffalo milk & 16.71 & 95.27 & 23.64 & -- & 38.78 & 32.85 & 4.73 & 23.50 & 3.80 \\
Starter & 90.50 & 92.06 & 17.46 & 4.85 & 3.98 & 65.77 & 7.94 & 71.46 & 11.52 \\
Berseem hay & 89.73 & 88.40 & 12.91 & 30.58 & 2.40 & 42.51 & 11.60 & 51.40 & 7.40 \\
\hline
\end{tabular}

* Calculated from tabulated values (APRI, 1997)

\section{Digestibility coefficients:}

Data in Table (2) showed that, DM, CP, CF and NFE digestbilities of R3 were significantly $(P<0.05)$ higher than $R 1$ (control). Also, CP and CF 
digestbilities of $R 2$ were significantly $(P<0.05)$ higher than $R 1$. Meanwhile, EE digestibility did not significantly differ among treatments. These results confirm those obtained by McCormick (1984), Nahshon et al. (1992) and Shimkus (2004).

Table (2): Digestion coefficients (\%) of different experimental treatments by buffalo calves at 10 weeks age.

\begin{tabular}{|l|c|c|c|}
\hline Nutrient & R1 & R2 & R3 \\
\hline DM & $71.64^{\mathrm{b}} \pm 0.98$ & $73.31^{\mathrm{ab}} \pm 0.49$ & $75.74^{\mathrm{a}} \pm 0.72$ \\
CP & $74.40^{\mathrm{b}} \pm 0.62$ & $76.90^{\mathrm{a}} \pm 0.65$ & $78.34^{\mathrm{a}} \pm 0.79$ \\
CF & $51.24^{\mathrm{b}} \pm 0.75$ & $53.91^{\mathrm{a}} \pm 0.94$ & $54.98^{\mathrm{a}} \pm 0.54$ \\
EE & $80.79 \pm 0.52$ & $81.11^{\mathrm{a}} \pm 0.95$ & $82.31 \pm 0.81$ \\
NFE & $76.45^{\mathrm{b}} \pm 0.75$ & $78.50^{\mathrm{a}} \mathrm{b} \pm 0.43$ & $79.85^{\mathrm{a}} \pm 0.91$ \\
\hline
\end{tabular}

a and b: Means within the same row with different superscripts significantly $(P<0.05)$ differ.

The improvement effects of MOS (R3) may be attributed to its ability to improve intestinal bacteria balance which help to improve nutrients digestibility (Dvorak et al., 1997).Kumprechtova and Lllek (2007) reported that, the goals of MOS supplementation include the optimization of intestinal microflora composition, increasing the nutrients absorption, prevention of intestinal disorders and achievement of better performance results. Pettigrew (2000) reported that the responses to MOS are real and important.

The improvement of probiotic (R2) may be attributed to its ability to induce the microbial aquilibrium of the jut in order to prevent gut digestive disorders and / or enhancing the growth of desirable gastrointestinal microbes of the host animals (Fuller, 1988 and Marionnet and Lebas, 1990). Sissons (1998) found that, probiotics supplement gives daily protection against any pathogens which may enter the animal's gut.This effect improves the process of digestion and absorption of nutrients. In addition, lactobacillus species present in the probiotics have been shown to produce digestive enzymes; amylase, protease and lipase, which may enrich the concentration of digestive enzymes (Moon and Kim, 1989 and Lee and Lee, 1990). Voia et al. (2000) reported that increased absorption capacity of nutrients as a result to probiotic supplementation may be due to faster development of ruminal mucosa, papillae and vascularization as microscopy of rumen of calves fed probiotic revealed.

\section{Feed intake:}

Results in Table (3) revealed that calves fed MOS (R3) recorded the highest total dry matter intake (DMI), it was higher than control by $9.11 \%$. While calves fed probiotic (R2) recorded medium total DMI, it was higher than control by $5.95 \%$. Control group (R1) recorded the lowest total DMI. These results are in accordance with those obtained by Jenny et al. (1991), AbuTarboush et al. (1996) and Hooge (2006). The improvement in total DMI may be due to the positive effect of MOS or probiotic on nutrients' digestibility as shown in Table (2). Since nutrients' digestibility recorded by calves fed MOS or probiotic were higher than those recorded by control calves (Abd El-Ghani, 2004 and Kumprechtova and Lllek, 2007). Moreover, calves fed diet supplemented with probiotic (R2) and MOS (R3) consumed starter 6.24 and 
Talha, M. H. et al.

$8.24 \%$ more than calves fed control diet (R1), respectively. These results are in accordance with those obtained by Newman et al. (1993); Dvorak et al. (1997) and Terre et al. (2007) who found that addition MOS to milk replacer significantly increased starter intake. While, Jacques and Newman (1994) reported that, starter intake tended to be insignificantly higher for young calves given MOS. On the other hand, Schwab et al. (1980) reported that when calves were fed probiotic, starter intake tended to increase. Furthermore, berseem hay as dry matter intake by calves fed supplemented diets with probiotic or MOS was more than intake by calves fed control diet by 13.43 and $23.88 \%$, respectively. These results agreed with those found by Tarakanov (1993) and Skorko - Sajko and Sajko (1997) who reported that MOS increased the intake and efficiency of utilization of roughage. Supplementation of probiotic may enhance roughage fermentation and/ or prompt in emptying the rumen, which may lead to increasing roughage intake (El-Basiony et al., 2001).

Table (3): Average daily intake* DM, TDN and DCP of buffalo calves fed different experimental treatments.

\begin{tabular}{|l|c|c|c|}
\hline Items & R1 & R2 & R3 \\
\hline Total DMI, kg/ calf/ day: & 1.647 & 1.745 & 1.797 \\
Milk & 0.462 & 0.462 & 0.462 \\
Starter & 0.850 & 0.903 & 0.920 \\
Berseem hay & 0.335 & 0.380 & 0.415 \\
Total TDN intake, kg/ calf/ day: & 1.515 & 1.582 & 1.616 \\
Milk & 0.647 & 0.647 & 0.647 \\
Starter & 0.679 & 0.721 & 0.735 \\
Berseem hay & 0.189 & 0.214 & 0.234 \\
Total DCP intake, g/ calf/ day: & 240 & 251 & 256 \\
Milk & 104 & 104 & 104 \\
Starter & 109 & 116 & 118 \\
Berseem hay & 27 & 31 & 34 \\
\hline
\end{tabular}

Calves were group fed (6 calves per each)

The average daily TDN and DCP intake presented in Table (3) followed similar trend to that recorded for DMI. These results agree with those obtained by El-Ashry et al. (2003) and El-Bordeny et al.(2005) for buffalo calves.

Daily body gain (DBG):

Data presented in Table (4) cleared that, average of initial body weight were nearly similar for different groups. The average of daily body gain (DBW) of calves fed R3 was significantly $(P<0.05)$ higher than those fed R1 during period from $2^{\text {nd }}$ week till $10^{\text {th }}$ week. While the average of DBG of calves fed R2 was significantly $(P<0.05)$ higher than those fed R1 during period from $2^{\text {nd }}$ week till $4^{\text {th }}$ week. Meanwhile, there were no significant differences among supplemented groups (R2 and R3). The trends of daily body gain during different weeks indicated that the average of DBG was higher $(P<0.05)$ for calves fed supplemented rations ( $R 2$ and $R 3)$ than calves of control group (R1) during the first weeks of experiment. 
Table (4) Average daily gain of buffalo calves fed experimental treatments.

\begin{tabular}{|l|c|c|c|}
\hline Items & $\mathbf{R 1}$ & $\mathbf{R 2}$ & $\mathbf{R 3}$ \\
\hline Calves, no & 6 & 6 & 6 \\
Initial weight, kg & $37.17 \pm 1.47$ & $39.33 \pm 1.61$ & $37.50 \pm 1.18$ \\
Average daily gain, kg/ day: & & & \\
$\quad 2^{\text {nd }}$ week & $0.394^{\mathrm{b}} \pm 0.03$ & $0.515^{\mathrm{a}} \pm 0.04$ & $0.561^{\mathrm{a}} \pm 0.04$ \\
$\quad 4^{\text {th }}$ week & $0.416^{\mathrm{b}} \pm 0.02$ & $0.536^{\mathrm{a}} \pm 0.03$ & $0.571^{\mathrm{a}} \pm 0.03$ \\
$6^{\text {th }}$ weeks & $0.500^{\mathrm{b}} \pm 0.04$ & $0.584^{\mathrm{ab}} \pm 0.03$ & $0.654^{\mathrm{a}} \pm 0.03$ \\
$8^{\text {th }}$ weeks & $0.607^{\mathrm{b}} \pm 0.03$ & $0.679^{\mathrm{a} b} \pm 0.03$ & $0.774^{\mathrm{a}} \pm 0.02$ \\
$1^{\text {th }}$ weeks & $0.679^{\mathrm{b}} \pm 0.05$ & $0.750^{\mathrm{ab}} \pm 0.05$ & $0.869^{\mathrm{a}} \pm 0.04$ \\
$12^{\text {th }}$ weeks & $0.869^{\mathrm{b}} \pm 0.06$ & $0.869 \pm 0.04$ & $0.905 \pm 0.07$ \\
$15^{\text {th }}$ weeks & $0.952 \pm 0.06$ & $0.960 \pm 0.03$ & $0.976 \pm 0.06$ \\
Overall mean & $0.660^{\mathrm{b}} \pm 0.03$ & $0.722^{\mathrm{ab}} \pm 0.01$ & $0.779^{\mathrm{a}} \pm 0.02$ \\
\hline
\end{tabular}

$a$ and $b$ : Means within the same row with different superscripts significantly $(P<0.05)$ differ.

During the whole suckling period, addition of MOS (R3) significantly $(P<0.0)$ increased average DBG by $18.03 \%$ compared to control (R1). Meanwhile, addition of probiotic (R2) insignificantly increased average DBG by $9.39 \%$ compared to R1. Whereas, the differences between supplemented groups (R2 and R3) were insignificant. Improving of average DBG of calves fed supplemented rations may be due to the positive effect of MOS and probiotic on DM intake and nutrients digestion as shown in tables 2 and 3 (Gaafar et al., 2005; Saleh et al., 2005 and Kumprechtova and Lllek, 2007). Also, the improved DBG of calves fed MOS may be due to its mod of action: 1) bind to cell wall of bacteria preventing the bacteria to attach to intestinal epithelial cells (Spring et al., 2000); 2) MOS may enhance the immune system by evoking a direct antibody response (Newman and Newman, 2001). On the other hand, improved DBG of calves fed probiotic may be a result to favorable growth of useful bacteria which colonized in intestine more quickly than pathogenic bacteria (Abe et al., 1995). These results are in harmony with those observed by Abe et al. (1995); Dildey et al. (1997). Gaafar et al. (2005) and Wolber et al.(2007). Calves fed diet supplemented with MOS gained approximately $19 \%$ (Newman et al., 1993), or $14.40 \%$ (Dvorak et al., 1997) faster than those fed control diet. Regarding probiotic, DBG of calves fed diet supplemented by probiotic was better than those fed control diet by about $7 \%$ (Thomas et al., 1974). On the other hand, some studies showed no effect on DBG with adding MOS to young calves diets (Terre et al., 2007) or probiotic (Morrill et al., 1977 and Owen and Larson, 1984 ).

Blood serum parameters :

Concentrations of total protein, albumin and globulin for treatment R3 were higher $(P<0.05)$ than the control and the $A / G$ ratio values for $R 3$ and $R 2$ were lower than those of control (Table 5 ). In general, R3 recorded the highest $(P<0.05)$ value of serum total protein followed by R2 then control. Concentration of total protein was higher $(P<0.05)$ by about 42.45 and $35.25 \%$ in R3 and R2 claves than control, respectivily. 
Talha, M. H. et al. 
J. Agric. Sci. Mansoura Univ., 34 (4), April, 2009 
Talha, M. H. et al.

The present results are in agreement with the results of El Ashry et al. (2002) who reported that supplementing suckling buffalo calves with probiotic and acidified milk increased their plasma total protein level as compared to the control claves. Abdel-Khalek et al. (2000) and Ragheb (2003) found that the concentration of total protein was higher in Lacto-Sacc calves than the control. The present results could be related to the beneficial effect of MOS and probiotic supplementation on increasing protein digestibility through the enzymatic effect of protease and alteration of amino acid profile of digesta due to increasing microbial protein synthesis (Williams, 1989 and Abdel-Khalek et al., 2000).

These results were parallel with the results of CP digestibility (Table 2), which indicated better utilization of dietary protein through digestive tract. These results agree with the conclusion of Kumar et al. (1980) who reported that there was a positive correlation between dietary protein and serum protein concentration. Yousef and Zaki (2001) noticed that the increase in digestibility of CP may be a reason for the increase of serum total protein. Also, serum proteins are considered a reliable index reflecting health and performance characteristics of the animals (Kumar et al., 1980). This results may be attributed to the role of MOS and probiotic in improving most nutrients digestibility especially CP (Table 2). This probably led to an increase in the absorption rate from digestive tract (Lee and Lee, 1990).

Albumin concentration in blood serum was significantly $(P<0.05)$ lower in control than R3 (Table 5). In other words R3 and R2 recorded the highest values of serum albumin by about 21.11 and $16.07 \%$ than R1, respectivily. The present results are in agreement with that of Abdel-Khalek et al. (2000) and Ragheb (2003) working on Lacto-Sacc. El Ashry et al. (2002) reported that supplementing suckling buffalo calves with probiotic and acidified milk increased the plasma albumin level relative to the control claves. The increase of albumin in response to MOS and probiotic supplementation may be associated with improved nitrogen absorption (Lee and Lee, 1990). Serum albumin have been shown to be a good indicator of nitrogen status, especially in small ruminants (Ingraham and Kappel, 1988; Gaskins et al., 1991 and Laborde et al., 1995). This results may be due to higher $(P<0.05)$ digestibility of crude protein for treated than control groups (Table 2). Rowlands (1980) reported that dietary protein could affect the concentration of serum albumin. Saleh et al. (2005) noticed that the increase in digestibility of CP may be a reason for the increase of albumin concentration. On the other hand, El-Ashry et al. (2004) reported that the increase in serum albumin of heifer claves supplemented with Lacto-Sacc may be due to the role of growth promoter on decreasing the deamination of amino acids. Albumin acts as a significant mobile protein store for amino acids. (White et al., 1959). Data obtained suggested the normal status of liver since, the liver is the main organ of albumin synthesis.

The globulin content in blood serum was the highest $(P<0.05)$ with $R 3$, while control had the lowest value (Table 5). Intermediate values of serum globulin were found for R2. There was no significant difference between R2 and R3.Concentration of globulin was higher by about 126.83 and $112.20 \%$ in R3 and R2 claves than control (Table 5). These results agreed with those 
obtained by El Ashry et al. (1994) using Lactobacillus concentrate (LBC) or probiotic, yeast culture and probiotic acidified milk (El Ashry et al., 2002) for suckling buffalo calves and using Lacto-Sacc on growing buffalo (El Ashry et al.,2004). There three studies revealed that such supplements caused increased in plasma globulin level relative to the control claves. Hussien (1986) attributed this increase mainly to the increase in globulin and development of the immune syatem. The increase in globulin level may be induced by an improved immune response in calves supplemented with MOS and probiotic. Chang and Mowat (1992) found that chromium supplied by yeast may have improved the immune response of calves due to increasing serum total immunoglobulin. The high levels of globulin of R3 treatment may indicate good developed immunity status (Kitchennham et al., 1975). Maxine (1984) reported that albumin tends to predominate over globulin in sheep and goats. While, Ragheb (2003) by using Lacto-sacc and acid pak on Friesian calves and Kholif and Khorshed (2006) reported that using yeast or selenized yeast supplemented caused decreased plasma globulin by about 14 and 23.4 $\%$ in treated than control calves. The globulin concentrations in T2 and T3 were within the normal values indicating good immunity status of animals.

Data obtained indicated that there were no significant differences among treatments regarding $A / G$ ratio (Table 5 ). These results agreed with those obtained by El Ashry et al. (1994, 2002 and 2004) and Kholif and Khorshed (2006). The $A / G$ ratio tended to decrease in response to any of the tested additives relative to the control.

The data also revealed significant effect of age on serum total protein and albumin, but not on globulin and $A / G$ ratio in all treatments (Table 5). It is worthy noting that, the effect of MOS and probiotic supplementation on total protein, albumin, globulin and $A / G$ ratio was observed at the $2^{\text {nd }}$ half of suckling period. The present results are in accordance with those obtained by Abdel-Khalek et al. (2000) who reported that the effect of lacto-sacc supplement on total protein and albumin was observed during the $2^{\text {nd }}$ half of suckling period.

Supplementation of MOS and probiotic decreased $(P<0.05)$ serum urea $-\mathrm{N}$ of claves by about 33.20 and $17.64 \%$ as compared to the control, respectively (Table 5). This may reflect a tendency for improved $\mathrm{N}$ utilization of feed. Ibrahim et al. (1997); Abdel-Khalek et al. (2000) and Ragheb (2003) found similar results in suckling Friesian claves fed whole milk supplemented with Lacto-Sacc as compared to the control. These results disagree with those obtained by Quigley et al. (1992) who found that plasma urea - N was unaffected due to inclusion of yeast culture in calf starter during preruminant stage.It is worthy noting that, the significant $(P<0.05)$ effect of MOS and probiotic supplement on urea-N was observed at 105 days of suckling period (Table 5).

Supplementation of MOS and ptobiotic did not affect concentration of creatinine in serum of claves during suckling period (Table 5). The present results are in agreement with those of Fayed (1995) and El-Ashry et al. (2004) who demonstrated that Lacto-Sacc had no significant effect on serum creatinine values of the treated animals provided that dietary protein was sufficient. 
Activity of AST increased by about 38.69 and $21.62 \%$ in serum of calves supplemented with MOS (R3) and Probiotic (R2) than control, respectively, while ALT decreased by about 14.4 and $8.48 \%$ in serum of calves supplemented with MOS (R3) and probiotic (R2) as compared to the control (Table 5). Ragheb (2003) found similar results with suckling Friesian claves fed whole milk supplemented with lacto-sacc and acid pak. The present results disagree with the results obtained by Abdel-Khalek et al. (2000) and Kholif and Khorshed (2006) who reported that values of serum AST and ALT were not significantly affected by using yeast or selenized yeast treatments. The values of serum AST and ALT obtained in the present study are comparatively higher and lower, respectively than the normal rangs for claves which may be due to several factors such as feeding practices, genetics control, response to stress, age, liver function and body weight (Boots et al., 1969). On the other hand, the lower values in the present study may be due to differences in the plan of nutrition or to differences in the duration of feeding experiment.

Activities of both AST and ALT were significantly $(P<0.05)$ affected by age. Thus age and interaction of age level of MOS and probiotic caused changes in the activity of serum AST and ALT. However, AST and ALT activities reached peaks at 35 to 70 days of age and were slightly decreased with the progress of age. These results disagree with those obtained by Abdel-Khalek et al. (2000) who found that a supplement of Lacto -Sacc did not affect activities of AST and ALT in plasma of claves during the suckling period.

Supplementation of MOS and probiotic increased $(P<0.05)$ concentration of total lipids by about 17.62 and $7.52 \%$ and decreased cholesterol concentration by about 13.21 and $9.19 \%$ in serum of MOS and probiotic claves as compared to the control, respectively (Table 5). Mean values of serum cholesterol for treated animals ( $R 2$ and $R 3$ ) were significantly $(\mathrm{P}<0.05)$ lower than that of control animals. Abdel-Khalek et al. (2000) and Ragheb (2003) working on Friesian calves and El-Ashry et al. (2004) on buffalo claves, reported similar trend of reduction in cholesterol in milk supplemented with Lacto-Sacc. The current study indicated that increasing total lipids was associated with decreasing cholesterol as affected by MOS and probiotic supplementation. O.Kelly (1987) reported that cattle lack homeostatic mechanism for cholesterol regulation in blood and its amount depends on the quantity of long - chain fatty acids absorbed from alimentary tract. In light of the previous results, MOS and probiotic may lead to somewhat alteration in bacterial lipids content by stimulation of bacterial lipids synthesis (Williams, 1989). Furthermore, MOS and probiotic as a yeast culture has anticholesterokeamic effect (Fuller, 1989).

During the suckling period, significant $(P<0.05)$ differences were noticed earlier in cholesterol (started at 35-70 days) than that in total lipids (at 70-105 days) (Table 5). These results were similar with those obtained by Abdel-Khalek et al. (2000).

Supplementation of MOS and probiotic did not affect serum triglycerides concentrations of claves during the suckling period (Table 5). The concentration of triglycerides tended to decline in treated than control 
calves. The present results are in agreement with those of Antunovic et al. (2006).

Supplementation of MOS and probiotic increased $(P<0.05)$ glucose level by about 32.83 and $23.82 \%$ in serum of MOS and probiotic claves as compared to the control, respectively (Table 5). The higher glucose level in blood may be related to rapid rate of hydrolysis and absorption of the dietary carbohydrates in the alimentary tract. The present results are in accordance with those obtained by Abdel-Khalek et al. (2000). The higher level of glucose as affected by MOS and probiotic supplementation may be related to the effect of MOS and probiotic through activity of amylase that lead to increasing carbohydrates hydrolysis in the small intestine of suckling claves into glucose as end- product (Williams, 1989).

The glucose level reached a peak at 35 to 70 days of age and was slightly decreased with the progress of age. The data also revealed significant effect of age on serum glucose level. Such pattern of response is in agreement with that reported by Abdel-Khalek et al. (2000) who found that the increase of glucose level was significant $(P<0.05)$ at earlier suckling period.

From the present study, it can be concluded that MOS and probiotic supplementation for growing buffalo claves induced increases by about 4.15 and $2.17 \%$ of $\mathrm{Zn}$ and induced significant $(\mathrm{P}<0.05)$ increases by about 42.45 and $29.54 \%$ of Fe levels in serum of MOS and probiotic groups as compared to the control, respectively (Table5). The increase in serum $\mathrm{Zn}$ and Fe levels may be due to the apparent effect of MOS and probiotic on minerals release from the animals body, in which MOS and probiotic supplementation has been shown to protect animals against the stress which induces losses of several trace elements such as $\mathrm{Zn}, \mathrm{Fe}, \mathrm{Cu}$ and $\mathrm{Mn}$ in claves. Such pattern is in agreement with that reported by Chang and Mowat (1992). On the other hand, it is well known that immunoglobulin production is regulated by specific enzymes that have a trace elements at their core, the most common being $\mathrm{Zn}$ , Cu and Fe (Fielden and Rotilio, 1984). Possibly, MOS and probiotic may participated in certain enzymes that increase immunoglobulin synthesis which indirectly affect immunoglobulin levels.

There were significant $(P<0.05)$ differences in serum $\mathrm{Zn}$ and Fe levels among the age of claves under consideration (Table5).

In general, the present values of blood constituents are within the normal range reported for suckling buffalo claves (El Ashry et al., 2002) and indicate the beneficial effect of MOS and probiotic on improvement of protein, fat and carbohydrate metabolism without any adverse effects on kidney and liver function of MOS and probiotic claves.

\section{Feed conversion:}

Results obtained for feed conversion (kg DM, TDN and DCP/kg gain) are presented in Table (6). It is observed that, calves fed non supplemented diet (R1) were less efficient compared with those fed diets supplemented with probiotic or MOS (R2 or R3). On the other hand calves fed R3 had the best efficiency as $\mathrm{kg}$ DM, TDN, and DCP/ $\mathrm{kg}$ gain. The results showed that calves fed R2 or R3 converted their diets to live weight gain more efficiently than those fed R1. The improvement of feed conversion for calves fed 
supplemented diets compared to those fed control diet might be attributed to the increased efficiency of nutrients absorption and / or nutrients utilization or both (Roberton and Chevalier, 1997 and Kumprechtova and Lllek, 2007). These results agreed with those obtained by Abe et al., (1995), Sandi and Muhlbach (2001); Wolber et al. (2007) Gaafar et al. (2005). They found that MOS or probiotic supplementation improved feed conversion of newborn calves.

\section{Some health problems:}

The results pertaining to the incidence of diseases indicate that the calves mostly suffered from diarrhea (Table 6). Data obtained from this showed that MOS and probiotic supplementation (R3 and R2) resulted in lower percentages of incidence of diarrhea (16.67 and 33.33\%, respectively) compared to control (66.67\%). The improvement due to feeding MOS or probiotic may be attributed to their ability to produce acidic in rumen media which make it unsuitable for normal growth of bacteria causing diarrhea (ElAshry et al., 1994 and Choi et al., 1994). MOS enhance health by stimulating antibody production (Savage et al., 1996) or by affecting intestinal morphology and function (lji et al., 2001). Also, probiotic has an enhancement immune response and increase white blood cells (Abou'l Ella et al., 2003). Theses findings are in accordance with Newman et al. (1993); Ibrahim et al. (1997); Heinrichs et al. (2003) and Shitta (2005).

From the previous data, it could be noticed that calves are quite susceptible to diseases during the early stages of life. Therefore, the beneficial effect of MOS and probiotic during the early stages of life. These results would support recommendation of the prophylactic use of MOS and probiotic in first weeks of calf's life. Evidence of beneficial effects during the early stages of life in calves supplemented with MOS and probiotics has also been reported by Jenny et al. (1991); Quintero - Gonzalez et al. (1994); Cruywagen et al. (1996) and Skorko - Sajka and Sajko, (1997).

Table (6): Feed conversion; occurrence of diarrhea and economical evaluation of buffalo calves fed experimental treatments.

\begin{tabular}{|c|c|c|c|}
\hline Items & R1 & $\mathbf{R 2}$ & R3 \\
\hline \multicolumn{4}{|l|}{ Feed conversion*: } \\
\hline $\mathrm{Kg} \mathrm{DM} / \mathrm{kg}$ gain & 2.50 & 2.42 & 2.31 \\
\hline $\mathrm{Kg}$ TDN/ kg gain & 2.29 & 2.19 & 2.07 \\
\hline $\mathrm{Kg} \mathrm{DCP} / \mathrm{kg}$ gain & 0.364 & 0.347 & 0.328 \\
\hline Diarrhea, cases & 4 & 2 & 1 \\
\hline Economic evaluation: & & & \\
\hline Daily cost, LE/ head & 10.00 & 10.42 & 10.49 \\
\hline Daily cost, LE/ kg gain & 15.15 & 14.43 & 13.47 \\
\hline Relative cost of $\mathrm{kg}$ gain & 100 & 95.25 & 88.91 \\
\hline Weight gain price, LE & 11.88 & 13.00 & 14.02 \\
\hline Return, LE & 1.88 & 2.58 & 3.53 \\
\hline Return, LE/ kg gain & 2.85 & 3.57 & 4.53 \\
\hline Return improvement/ kg gain & -- & $25.26 \%$ & $58.95 \%$ \\
\hline Economic efficiency ${ }^{* *}$ & 1.19 & 1.25 & 1.34 \\
\hline
\end{tabular}

* Group feeding (6 calves per each).

** Economic efficiency = weight gain price/ daily cost.

Feedstuffs and body gain price:

Starter $=1500 \mathrm{LE} /$ ton Berseem hay $=750 \mathrm{LE} /$ ton $\quad \mathrm{MOS}=80 \mathrm{LE} / \mathrm{kg}$

Probiotic $=40 \mathrm{LE} / \mathrm{kg} \quad$ Buffalo milk $=3000 \mathrm{LE} /$ ton $\quad$ Body gain $=18 \mathrm{LE} / \mathrm{kg}$. 


\section{Economic efficiency:}

The cheapest daily cost/ $\mathrm{kg}$ gain was recorded for calves fed $\mathrm{R} 2$ and $\mathrm{R} 3$, while the expensive gain cost was found for calves fed R1 (Table 6). It was noticed that daily cost/ $1 \mathrm{~kg}$ gain decreased by $4.75 \%$ and $11.09 \%$ and return/ $1 \mathrm{~kg}$ increased by 25.26 and $58.95 \%$ for calves fed R2 and R3, respectively compared to those fed control ration. Better economic efficiency obtained with calves fed R2 and R3 may be due to increasing of daily body gain and decreasing daily cost for calves fed supplemented diets compared to control. These results are in agreement with those reported by Sandi and Muhlbach (2001) who found that feeding young calves diet supplemented by MOS reduced average cost/ kg body weight. Also, Gaafar et al. (2005) reported that feeding newborn calves diet supplemented by probiotic reduced feeding cost per kg gain.

\section{CONCLUSION}

It can be concluded that, supplementing milk of suckling buffalo calves with mannan oligosaccarides (MOS) or commercial probiotic product enhance feed intak, body weight gain, feed conversion, some blood parameters and rearing economic efficiency, with a higher superiority of MOS results.

\section{REFERENCES}

Abd El-Ghani, A. A. (2004). Influence of diet supplementation with yeast culture (Saccharomyces cerevisia) on performance of Zaraibi goats. Small Rumin. Res., 52: $223-229$.

Abdel-Khalek, A.E.; A.F. Mehrez and E.A. Omar (2000). Effect of yeast culture (Lacto-Sacc) on rumen activity, blood constituents and growth of suckling Friesian claves. Proc. Conf. Anim. Prod. In the 21th Century, Sakha, 18-20 April: 201-210.

Abe, F.; N. Ishibashi and S. Shimamura (1995). Effect of administration of bifidobacteria and lactic acid bacteria to newborn calves and piglets. J. Dairy Sci., 78: 2838 - 2846.

Abou'l Ella, A. A.; A. N. Sayed; S. G. Abdo and M. M. Khorshed (2003). Effect of commercial probiotic supplementation on the productive performance of lactating ewes. Egyp. J. Nutr. and Feeds, 6 (Special Issue): $1023-1033$.

Abu - Tarboush, H. M.; M. Y. Al - Saiady and A. H. Keir El - Din (1996). Evaluation of diet containing Lactobacilli on performance, fecal coliform and Lactobacilli of young dairy calves. Anim. Feed Sci. Technol., 57: 39 -49 .

Amabile - Cuevas, C.; Cardenas - Garcia, M.; Ludgar, M. (1995). Antibiotic resistance. Am. Sci., 83, 320 - 329.

Antunovic, Z.; S. Marcela; D. Amidzic; V. Seric; Z. Steiner; M. Domacinovic and F. Boli (2006). Probiotic application in lambs nutrition. Krmiva, 48, Zgreb, 4:175-180. 
APRI (1997). Animal Production Research Institute. Animal Nutrition (Scientifically and practically) $1^{\text {st }}$ Ed. Animal Production Research Institute, Agricultural Research Center, Ministry of Agriculture, Dokki, Giza, Egypt (In Arabic).

A. O. A. C. (1999). Association of Official Analytical Chemists. Official Methods of Analysis. $13^{\text {th }}$ Ed. Washington D. C., U. S. A.

Bartels, H. (1971). Colorimetric determination of creatinine. Chem. Acta, 32: 81

Boots, L. R.; W. L. Ccrist; D. R. Davis; E. W. Brum and T. M. Ludwick (1969). Effect of age, body weight, stage of gestation and sex on plasma glutamic-oxaloacetic and glutamic-pyrucic transaminase activities in immature Holstein cattle. J. Dairy Sci., $52: 211$.

Chang, X. and D.N. Mowat (1992). Supplemental chromium for stressed and growing feeder calves. J. Anim. Sci., 70: 559.

Choi, K. H.; H. Namkung and L. K. Paik (1994). Effects of dietary fructooligosaccharides on the suppression of intestinal colonization of Salmonella typhimrium in broiler chickens. Korean J. Anim. Sci., 36: 271.

Cruywagen, C. W.; Ina Jordaan and L. Venter (1996). Effect of Lactobacillus supplementation of milk replacer on preweaning performance of calves. J Dairy Sci., 79: $483-486$.

Dawson, K. A. (1995). Current and future role of yeast culture in animal production: A review of research over the last seven years. Dept. of Anim. Sci. Book. PP. 269, Univ. of Kentucky, USA.

Dildey, D.; K. Sellars; M. Burrill; J. Trei; K. Newman and K. Jacques (1997). Effect of mannanoligosacchride supplementation on performance and health of Holstein calves. J. Dairy Sci., 80 (Suppl.): 188.

Doumas, B.T. and H.G. Biggs (1972a). The colorimetric determination of total protein in serum or plasma. Standard Methods of Clinical Chemistry. Vol 7. Academic Press. New York.

Doumas, B.T. and H.G. Biggs (1972b). The colorimetric determination of albumin in serum or plasma. Standard Methods of Clinical Chemistry. Vol 7. Academic Press. New York.

Dvorak, R. A.; K. A. Jacques and K. E. Newman (1997). The effect of Bio MOS supplementation of milk replacers for calves. J. Anim. Sci., (Suppl. 1): 22.

El- Ashry, M.A; A.Z.El-Basiony; A.M. El-Serafy and M.F. Sadek (1994). Probiotic (LBC) in buffalo heifers ration: 2- Effect on some blood parameters. Egyp. J. Anim. Prod. 31, (1):15-25.

El- Ashry,M.A; H.M. El-Sayed; Hana M.El-Koussy; M.M. Khorshed; H.M. Saleh and A.K. Ammar. (2004). Effect of lacto-sacc on feed efficiency, some blood constituents and reproductive performance growing Egyptian buffalo heifers. Egyp. J. Nutr. and Feeds 7, (1):97-108.

El- Ashry, M.A.; Salwa, M. Hamdy; A. M. Mansour; M. M. Khorshed and E. M. El - Kotamy (2003). Studies on performance of buffalo calves fed on acidified. Egyp. J. Nutr. and Feeds, 6 (1) : 1-11.

El- Ashry, M.A.; Zeba A. Motagally and Y.A. Maareck. (2002). Effect of live dried baker's yeast with or without acidification of milk and of yeast culture on performance of suckling buffalo calves. Egyp. J. Nutr. and Feeds 5 (1): 31-41. 
El-Basiony, A. Z.; H. M. El - Sayed; E. E. Ragheb; M. A. El - Ashry and A Srour (2001). Effect of pronifer supplementation on the performance of buffalo calves at different stages of growth and fattening. Egyp. J. Nutr. and Feeds, 4 (Special Issue) : $641-649$.

El - Bordeny, N. E.; M. A. El - Ashry; H. H. Khattab and H. M. El - Sayed (2005). Effect of some medicinal herbs on buffalo calves performance from first week till weaning. Egyp. J. Nutr. and Feeds, 8(1) (Special Issue): $155-166$.

El - Garhy, M. M.; A. A. El - Rashidy; K. N. Mettias; E. Hassan and H. M. Hassan (1994). Studies on neonatal diarrhea in buffalo calves. IV th. World Buffalo Cong. Sanpaulo, Brazil.

Fadl Allah, Manal, G. M. (1996). Studies on the therapeutic approach of diarrhea in suckling calves. Ph.D. Thesis, Fac. of Vet. Med. (Internal medicine), Cairo Univ.

Fayed, M.M.A. (1995). Factors affecting productive performance of buffalo male claves till slaughter. Ph.D. Thesis Fac. of Agric. Ain Shams Univ. Egypt.

Fielden, E.M. and G. Rotilio (1984). The structure and mechanism of Cu / Zn super oxide dismutase. In: R. Lontie (Ed.). Copper Proteins and Copper Enzymes Vol. II. P 27. CRC Press, Boca Raton, FL.

Fuller, R. (1988). Basis and efficacy of probiotics. World's Poul. Sci. J., 44 (1) pp. 69.

Fuller, R. (1989). Probiotics in man and animals. A Rev. J. Appl. Bacteriol, 66:365-378.

Gaafar, H. M. A.; A. A. Shitta and E. A. Omer (2005). Probiotic supplementation for suckling Friesian calves. 1 - Productive performance. Egyp. J. Nutr. and Feeds, 8 (2): 163 - 173.

Gaskins, H.R.; W.J. Croom, Jr; J.M. Fernandez; J.E. Van Eys; W.M. Hagler, $\mathrm{Jr}$ and W.L.Johnson (1991). Metabolic responses to protein supplementation and slaframine in goats and sheep fed roughage. Small Rumin. Res., 6: 73-84.

Heinrichs, A. J.; C. M. Jones and B. S. Heinrichs (2003). Effects of mannan oligosaccharide or anitibiotics in neonatal diets on health and growth of dairy calves. J. Dairy Sci., 86: 4064 - 4069.

Hooge, D. M. (2006). Use of MOS to improve weight and health in calves. Albeitar, 98: $56-57$

Hussien, H.M. (1986). Effect of different feeding systems on some blood parameters in male buffalo claves. Ph.D. Thesis, Fac. of Agric. Ain Shams Univ. Egypt.

Ibrahim, I. L.; A. M. El - Gaafarawy and E. A. Omar (1997). Effect of adding probiotics to Freiesian calves diet on their growth performance. J. Agric. Sci. Mansoura Univ., 22 (4): 1035 - 1045.

Iji, P. A.; A. A. Saki and D. R. Tivey (2001). Intestinal structure and function of broiler chickens on diets supplemented with a mannan oligosaccharaide. J. Sci. Food Agric., 81: 1186 - 1192.

Ingraham, R.H. and L.C. Kappel (1988). Metabolic profile testing. Vet. Clin. North Am. Food Pract., 4: 391-411.

Jacques, k. A. and K. E. Newman (1994). Effect of oligosaccharide supplements to milk replacer on calf performance and health pre weaning. J. Anim. Sci., 72 (suppl. 1): 295 (Abstr.). 
Jenny, B. F.; H. J. Vandijk and J. A. Collins (1991). Performance and fecal flora of calves fed a Baillus subtilis concentrate. J. Dairy Sci., 74: 1968 $-1973$.

Kamra, D. N. and N. N. Pathak (2005). Improvement in livestock productivity by use probiotics: A review. Indian Anim. Sci., 75: 128 - 134 .

Kholif, S.M. and M.M. Khorshed (2006). Effect of yeast or selenized yeast supplementation to rations on the productive performance of lactating buffaloes. Egyp. J. Nutr. and Feeds 9 (2) : 193-205.

Kitchennham, B.A.; G.J. Rowlands; R. Manston and S.A. Dew (1975). The blood composition of dairy calves reared under conventional and rapid growth system. Brit. Vet. J., 31.

Kumar. N. U. B.; B. Singh and D. N. Verma (1980). Effect of different levels of dietary protein and energy on growth of male buffalo calves. Ind. J .Anim. Sci., 51:513.

Kumprechtova, D.; J. Lllek (2007). Use of mannan oligosaccharides isolated from the cell wall of yests in calf nutrition. Veterinarstvi, 57 (4): $255-$ 256.

Laborde, C.J.; A.M. Chapa; D.W. Burleigh; D.J. Salgado and J.M. Fernandez (1995). Effects of processing and storage on the measurement of nitrogenous compounds in ovine blood. Small Rumin. Res., 17: 159166.

Lee, S.Y. and B.H. Lee (1990). Esterlytic and lipolytic activities of Lactobacillus casei-subsp-casei LLG.J. Food Sci., 55: 119.

Malik, R.; D. D. Sharma and R. Malik (1998). Influence of mixed probiotic on growth, feed conversion efficiency and incidence of diarrhea in young calves. Indian J. Anim. Nutr., 15: 228 - 231.

Marionnet, D. and F. Lebas (1990). What is a probiotic. Cuniculture, Limpdes. Paris, No, 96: $225-258$.

Matter, Badr, B.; H. M. Radwan and N. A. Ibrahim (2005). Soymilk as buffalo substitute in feeding newborn buffalo calves. 1 - The effect of replacement of whole buffalo milk by soybean milk on suckling buffalo calves performance. Egyp. J. Agric. Res., 83 (1):389 - 403.

Maxine, M. B. (1984). Outline of Veterinary Clinical Pathology. (Fourth Ed.), The lowa State Univ. Press lowa USA.

McCormick, M. E. (1984). Probiotic in ruminant nutrition and health. Proc. Gorgia Nutr. Conf. Feed Ind., pp. 62.

Moon, T. I. and Y. K. Kim (1989). Study on the proteolytic action of intracellular protease of lactobacillus bulgaricns. Koream J. Dairy Sci., 11: 34.

Morrill, J. L.; A. D. Dayton and R. Mickelsen (1977). Cultured milk and antibiotics for young calves. J. Dairy Sci., 60: 1105.

Nahshon, S. N.; H. S. Nakaue and L. W. Mirosh (1992). Effect of direct fed microbial on nutrient retention and production parameters of lying pullets. Poul. Sci., 71: 11.the microflora and immunoglobulin satus of sows and piglet performance. J. Anim. Sci., 79 (Suppl.1): 189 (Apstr.).

Newman, K. E.; K. Jacques and R. Buede (1993). Effect of mannan oligosaccharide on performance of calves fed acidified and non acidified milk replacers. J Anim. Sci., 71 (Suppl.1): 271 (Abstr.).

Newman, K.E. and M.C. Newman (2001). Evaluation of mannan oligosaccharide on the microflora and immunoglobulin satus of sows and piglet performance. J. Anim. Sci., 79 (Suppl.1): 189 (Abstr.). 
O, Kelly, J.C. (1987). Influence of dietary fat on some metabolic responses of cattle to hyperthermia induced heat exposure., Comp. Biochem. Physiol. 87A:667-682.

Owen, F. G. and L. L. Larsen (1984). Effect of probiocin and starter preparations on calf performance. J. Dairy Sci., 61 (Suppl. 1): 139 (Abstr.).

Perdigon, G. and S. Alvarez (1992). Probiotics and the immune status. In Probiotics, Roy Fuller, Chapman \& Hall. pp. 146.

Pettigrew, J. E. (2000). Bio - Mos effects on pig performance. A review. In: Biotechnology in Feed Industry, Proc. of $16^{\text {th }}$ Annual Symposium (T. P. Lyons and K. A.Jacques, Eds). pp. 31. Nottingham Univ. Press. Nottingham, Leics. UK.

Pollmann, D. S.; D. M. Danielson and E. R. Peo (1980). Effects of microbial feed additives on performance of starter and growing finishing pigs. J. Anim. Sci., 51: 577.

Quigley, J.D.; L.B. Wallis; H.H. Dowlen and R.N. Heitmann. (1992). Sodium Bicarbonate and yeast culture effects on ruminal fermentation, growth and intake in dairy calves. J. Dairy Sci., 75: 3531.

Quintero - Gonzalez, C. I.; J. W. Comerford; G. A. Varga and T. W. Cassidy (1994). Effects of direct - fed microbials on productivity and blood parameters in young calves. J. Dairy Sci., 77 (Suppl. 1): 89. (Abstr.).

Ragheb,E.E. (2003). Effect of Lacto-sacc and Acid pak additives on productive performance of Friesian claves under early weaning system. Egyp. J. Nutr. and Feeds 6 (2):127-137.

Reitman, S. and S. Frankel (1957). Acolorimetric method for determination of serum glutamic oxaloacitic and glutamic pyruvic transaminases Amer. J. Clin. Path., 28, 56-63.

Roberton, J. L. and S. Chevalier (1997). Probiotics in pigs and poultry nutrition. ESVIM Conf., France.

Rowlands, G. J. (1980). A review of variation in the concentration of metabolism in the blood of beef dairy cattle associated with physiology, nutrition and disease with particular reference to the interpretation of metabolic profiles. Wid. Rev. Nutr. Diet., 35:172.

Rusoff, L. L.; A. H. Cummings; E. J. Stone and J. E. Johnston (1959). Effect of high level administration of chlortetracycline at birth on the health and growth of young dairy calves. J. Dairy Sci., 42: $856-862$.

Saleh, M. S.; A. M. Metwally and M. Abd El - Momin (2005). Effect of feeding rations supplemented with Biogen on digestibility and performance of growing lambs. Egyp. J. Nutr. and feeds, 8 (1) (Secial Issue) : $635-$ 646.

Sampath, S. R. (1989). Feeding and nutrition of calf. A talk delivered at the XXIII Dairy Industry Conference, held at APDDCFL, Hyderabad, Dec., $9-11,1989$.

Sandi, D. and P. R. F. Muhlbach (2001). Performance of Holstein bull calves weaned at 28 or 56 days of age, with or without additive based on mannan oligosaccharide. Ciencia - Rural, 31 (3): 487 - 490.

Savage, T. F.; P. F. Cotter and E. I. Zakrzewska (1996). The effect of feeding a mannan oligosaccharide on immunoglubulins, plasma $\lg A$ and bile $\lg$ A of Wrolstad MW mal turkeys. Poult. Sci., 75 (Suppl.): 143 (Abstr).

Schwab, C.G.; J. J. Moore; P. M. Hoyt and J. L. Prentice (1980). Performance and fecal flora of calves fed a nonviable Lactobacillus bulgaricus fermentation product. J. Dairy Sci., 63: 1412. 
Shimkus, A. (2004). Prebiotic and synbiotic preparations in calf feeding. Bulgarian J. Agric. Sci., 10 (4):491 - 498.

Shitta, A. A. (2005). Commercial probiotic supplementation for suckling Friesian calves: 2 - Immune response and mortality rate. J. Agric. Sci., Mansoura Univ., 30 (8): 4451 - 4460.

Sissons, J. W. (1998). The potential of probiotic organisms to prevent diarrhea and promote digestion. Proc. $4^{\text {th }}$ Int. Seminar, Poland, pp. 457.

Skorko - Sajko, H. and j. Sajko (1997). Effect of mannan oligosacchrides on rearing results of calves. Acta - Academiae Agric. Technicae Olstensis, Zootechnica, 47: 87 - 94.

Spring, P.; C. Wenk; K. A. Dawson and K. E. Newman (2000). The effects of dietary mannan oligosacchrides on cecal parameters and the concentrations of enteric bacteria in the ceca of salmonella challenged broiler chicks. Poult. Sci., 79: $205-211$.

SPSS (1999). Statistical package for the social sciences, Release 10, SPSS Inc., Chicago, USA.

Talk, H. and G. E. Schubert (1965). Enumatic urea determination in serum and plasma, Klin. Wochenschr, 43: 174.

Tarakanov, B. V. (1993). Biopreparations for raising the efficiency of feed utilization. Zootekhniya, 8: 16-18.

Terre, M.; M. A. Calvo; C. Adelantado; A. Kocher and A. Bach (2007). Effects of mannan oligosacchrides on performance and microorganism fecal counts of calves following an enhanced - growth feeding program. Anim. Feed Sci. and Techn., 137: $115-125$.

Thomas, R. O.; R. C. Hatch and W. V. Thayne (1974). Effect of Lactobacillus acidophilus as an additive to the feed of baby calves. West Virginia Agric. Forest., $5: 15$.

Van Keulen, J. and B. A. Young (1977). Evaluation. of acid - insoluble ash as a natural marker in ruminants digestibility studies. J. Anim. Sci., 44: 282 $-287$.

Voia, O.; D. Drinceanu; G. Dumitrescu and I. Padeanu (2000). The effect of the preparation prosimbiont $B$ on morphological changes of the rumen in suckling lambs. Lucrai Stiintifice Zootehnie si Biotehnologii Vniversitatea de stiinte Agricole si Medicina Veterinara a Banatului Timisoara, 33: 169 - 174 (Abstr.).

White, A.; H.P. Emil and S. Dewitt (1959). Principales of Biochemistry. 2nd ed. McGraw-Hill Book Company, INC. London, UK.

Williams, P.E.V. (1989). The mode of action of yeast culture in ruminal diets. A review of the effect of rumen fermentation patterns. pp. 65 in Biotechnology in the feed industry. Alltech TECH. Publ. Nicholasville.

Windschitl, P. M. (1992). Effect of probiotic supplementation of hulless barely and corn based diets on bacerial fermentation in continuous culture of ruminal contents. Cand. J. Anim. Sci., 72: 265.

Wolber, F. M.; D. Dey; R. Lentle and L. Fray (2007). Prebiotic supplementation increases Lactobacillus species stability, immune cell function and feed conversion efficiency in neonatal calves. Proc. of the Nutr. Society of new Zealand, 30: 176.

Yousef, H.M. and A.A. Zaki (2001). Effect of barley radical feeding on body weight gain and some Physiological parameters of growing Friesian crossbred calves. Egyp. J. Nutr. and Feeds, 4 (Special Issue) : 465472. 


\section{تأثير بعض الإضافات الغذائية في تنشئة العجول من الميلاد حتى الفطام}

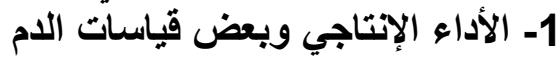

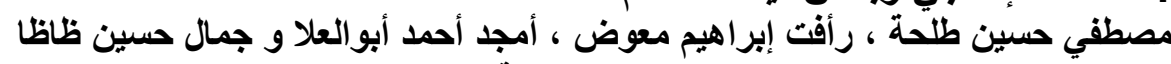

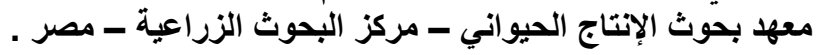

استخدم في هذا البحث 18 عجل و عجلة جاموسي رضيعة قسمت حسب وزنها وجنه وجنسها إلى ثلاثنة

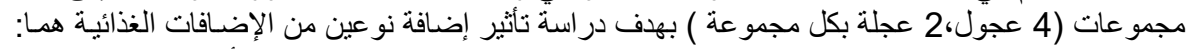
probiotic

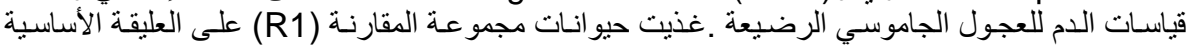

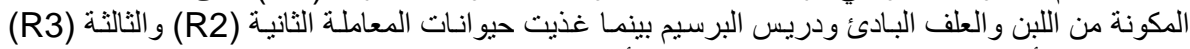

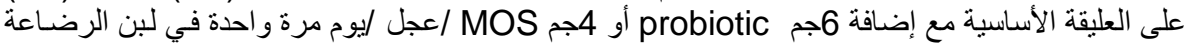

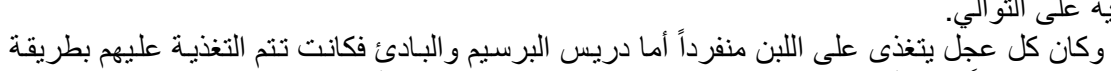

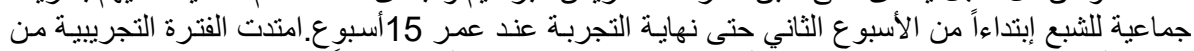

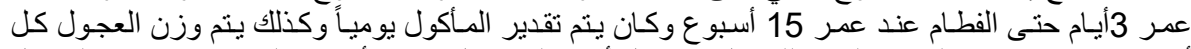

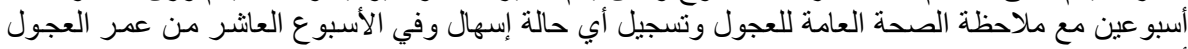

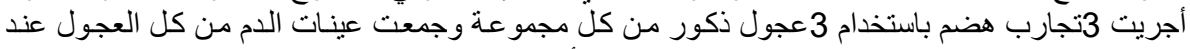

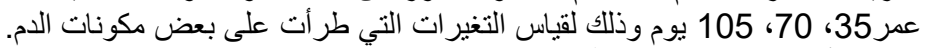
فيما يلي أهم نتائج هذه الاراسة:-

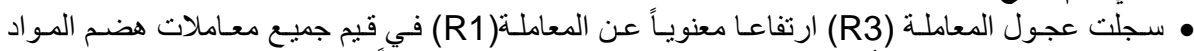

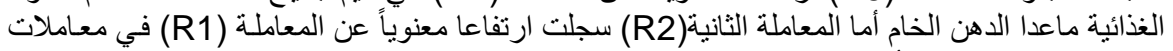

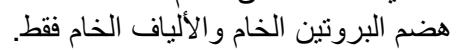

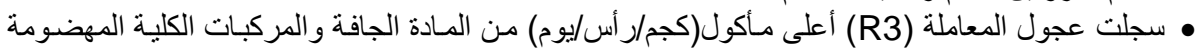

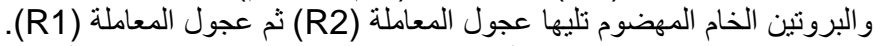

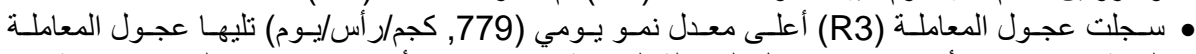

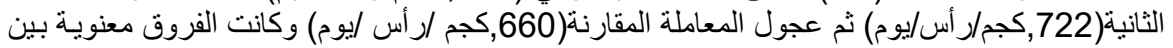
المعاملة R1،R3 فقط.

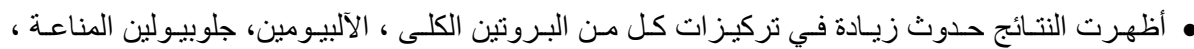

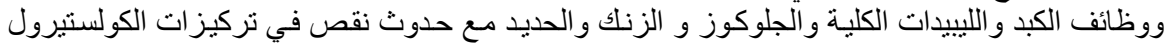

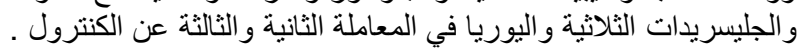

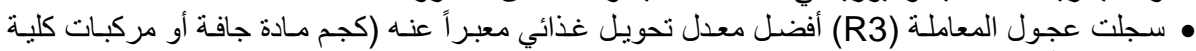

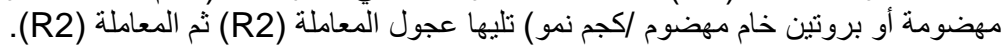

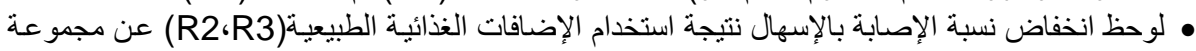
المقارنة. • أظهر التقييم الاقتصادي أن أقل تكلفة تغذية/كجم نمو كانت لحيو انات المعاملة(R3) تليها المعاملة)(R2) ثم

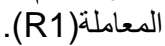

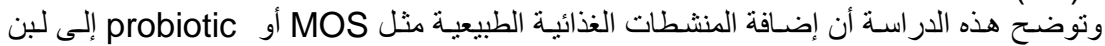

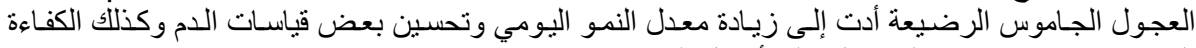

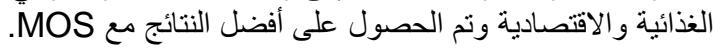



J. Agric. Sci. Mansoura Univ., 34 (4): 2763 - 2783, 2009

Table (5): Effect of MOS and probiotic supplementation on claves blood serum protein fraction, liver and kidney function and minerals after feeding.

\begin{tabular}{|c|c|c|c|c|c|}
\hline Blood components & Aches & & Treatments & 28 & Overallmean \\
\hline \begin{tabular}{|c|} 
Total protein \\
$(\mathrm{g} / \mathrm{dl})$
\end{tabular} & $\begin{array}{l}35 \\
70 \\
105 \\
\text { Overall mean }\end{array}$ & $\begin{array}{c}4.10 \pm 0.08 \\
4.41 \pm 0.39 \\
4.00 \pm 0.07 \\
4.17^{\mathrm{b}} \pm 0.18\end{array}$ & $\begin{array}{l}6.55 \pm 0.36 \\
5.94 \pm 0.57 \\
4.44 \pm 0.58 \\
5.64^{\mathrm{a}} \pm 0.50\end{array}$ & $\begin{array}{l}5.72 \pm 0.21 \\
7.47 \pm 0.59 \\
4.62 \pm 1.17 \\
5.94^{\mathrm{a}} \pm 0.66\end{array}$ & $\begin{array}{l}5.46^{\mathrm{A}} \pm 0.22 \\
5.94^{\mathrm{A}} \pm 0.52 \\
4.35^{\mathrm{B}} \pm 0.61\end{array}$ \\
\hline$\underset{(\mathrm{g} / \mathrm{dl})}{\text { Albumin }}$ & $\begin{array}{l}35 \\
70 \\
105 \\
\text { Overall mean }\end{array}$ & $\begin{array}{l}2.94 \pm 0.47 \\
3.75 \pm 0.46 \\
3.36 \pm 0.20 \\
3.36^{ \pm} \pm 0.20\end{array}$ & $\begin{array}{c}3.78 \pm 0.50 \\
4.77 \pm 0.17 \\
3.16 \pm 0.17 \\
3.90^{\mathrm{ab}} \pm 0.28\end{array}$ & $\begin{array}{l}4.11 \pm 0.77 \\
5.03 \pm 0.42 \\
3.07 \pm 0.38 \\
4.07^{ \pm} \pm 0.52\end{array}$ & $\begin{array}{l}3.61^{\mathrm{B}} \pm 0.58 \\
4.52^{\mathrm{A}} \pm 0.35 \\
3.20^{\mathrm{B}} \pm 0.25\end{array}$ \\
\hline $\begin{array}{l}\text { Globulin } \\
(\mathrm{g} / \mathrm{dl})\end{array}$ & $\begin{array}{l}35 \\
70 \\
105 \\
\text { Overall mean }\end{array}$ & $\begin{array}{l}1.17 \pm 0.48 \\
0.66 \pm 0.29 \\
0.64 \pm 0.21 \\
0.82^{\ddagger} \pm 0.33\end{array}$ & $\begin{array}{r}2.77 \pm 0.17 \\
1.17 \pm 0.59 \\
1.28 \pm 0.56 \\
1.74^{\mathrm{ab}} \pm 0.44\end{array}$ & $\begin{array}{l}1.61 \pm 0.57 \\
2.44 \pm 0.91 \\
1.55 \pm 0.99 \\
1.86^{ \pm} \pm 0.82\end{array}$ & $\begin{array}{l}1.85^{\mathrm{A}} \pm 0.41 \\
1.42^{\mathrm{A}} \pm 0.60 \\
1.16^{\mathrm{A}} \pm 0.59\end{array}$ \\
\hline$A / G$ ratio & $\begin{array}{l}35 \\
70 \\
105 \\
\text { Overall mean }\end{array}$ & $\begin{array}{l}2.51 \pm 2.00 \\
5.68 \pm 4.79 \\
5.25 \pm 1.55 \\
4.59^{\mathrm{a}} \pm 2.78\end{array}$ & $\begin{array}{c}1.36 \pm 0.23 \\
4.04 \pm 0.90 \\
2.47 \pm 3.06 \\
2.62^{a} \pm 1.40\end{array}$ & $\begin{array}{l}2.55 \pm 1.46 \\
2.07 \pm 1.49 \\
1.98 \pm 1.48 \\
2.20^{\mathrm{a}} \pm 1.48\end{array}$ & $\begin{array}{l}2.14^{\mathrm{A}} \pm 1.23 \\
3.93^{\mathrm{A}} \pm 2.39 \\
2.23^{\mathrm{A}} \pm 2.03\end{array}$ \\
\hline AST (U/L) & $\begin{array}{l}35 \\
70 \\
105 \\
\text { Overall mean }\end{array}$ & $\begin{array}{c}18.83 \pm 12.14 \\
13.33 \pm 1.34 \\
12.67 \pm 1.77 \\
14.94^{\mathrm{b}} \pm 5.08\end{array}$ & $\begin{array}{c}29.00 \pm 3.47 \\
14.67 \pm 1.34 \\
10.83 \pm 1.17 \\
18.17^{\mathrm{aa}} \pm 1.99\end{array}$ & $\begin{array}{l}14.50 \pm 4.38 \\
27.00 \pm 4.00 \\
20.67 \pm 4.21 \\
20.72 \pm 4.20\end{array}$ & $\begin{array}{r}20.78^{\mathrm{A}} \pm 6.66 \\
18.33^{\mathrm{AB}} \pm 2.23 \\
14.72^{\mathrm{B}} . \pm 2.38\end{array}$ \\
\hline $\operatorname{ALT}(\mathrm{U} / \mathrm{L})$ & $\begin{array}{l}35 \\
70 \\
105 \\
\text { Overall mean }\end{array}$ & $\begin{array}{l}4.00 \pm 0.23 \\
4.33 \pm 0.34 \\
3.33 \pm 0.34 \\
3.89^{\mathrm{b}} \pm 0.30\end{array}$ & $\begin{array}{c}3.33 \pm 0.34 \\
4.00 \pm 0.23 \\
3.33 \pm 0.31 \\
3.56^{\mathrm{ab}} \pm 0.30\end{array}$ & $\begin{array}{c}3.33 \pm 0.34 \\
3.33 \pm 0.34 \\
3.33 \pm 0.25 \\
3.33^{\mathrm{a}} \pm 0.31\end{array}$ & $\begin{array}{l}3.55^{\mathrm{AB}} \pm 0.30 \\
3.89^{\mathrm{A}} \pm 0.30 \\
3.33^{\mathrm{B}} \pm 0.30\end{array}$ \\
\hline Total lipids (mg/dl) & $\begin{array}{l}35 \\
70 \\
105 \\
\text { Overall mean }\end{array}$ & $\begin{array}{l}402.12 \pm 43.90 \\
291.01 \pm 39.02 \\
354.98 \pm 17.40 \\
349.39^{\mathrm{b}} \pm 33.44\end{array}$ & $\begin{array}{l}316.14 \pm 26.39 \\
347.88 \pm 19.24 \\
462.96 \pm 66.85 \\
375.66^{\mathrm{a}} \pm 37.49\end{array}$ & $\begin{array}{l}456.35 \pm 75.69 \\
406.09 \pm 33.44 \\
370.37 \pm 42.69 \\
410.94^{\mathrm{a}} \pm 50.61\end{array}$ & $\begin{array}{l}391.54^{\mathrm{AB}} \pm 48.66 \\
348.33^{\mathrm{B}} \pm 30.57 \\
396.01^{\mathrm{A}} \pm 42.31\end{array}$ \\
\hline Triglycerides (mg/dl) & $\begin{array}{l}35 \\
70 \\
105 \\
\text { Overall mean }\end{array}$ & $\begin{array}{l}29.25 \pm 1.18 \\
24.49 \pm 12.94 \\
29.48 \pm 8.06 \\
27.74^{\mathrm{a}} \pm 7.39\end{array}$ & $\begin{array}{l}22.22 \pm 1.77 \\
28.38 \pm 8.77 \\
30.38 \pm 11.42 \\
27.13^{\mathrm{a}} \pm 7.32\end{array}$ & $\begin{array}{l}20.18 \pm 4.47 \\
24.26 \pm 7.13 \\
22.14 \pm 3.86 \\
22.19^{\mathrm{a}} \pm 5.15\end{array}$ & $\begin{array}{l}23.88^{\mathrm{A}} \pm 3.47 \\
25.71^{A} \pm 9.61 \\
27.33^{\mathrm{A}} \pm 7.78\end{array}$ \\
\hline Cholesterol (mg/dl) & $\begin{array}{l}35 \\
70 \\
105 \\
\text { Overall mean }\end{array}$ & $\begin{array}{l}105.57 \pm 3.36 \\
97.71 \pm 6.03 \\
93.53 \pm 19.25 \\
98.94 \pm 9.55\end{array}$ & $\begin{array}{l}107.17 \pm 1.90 \\
78.81 \pm 11.60 \\
83.58 \pm 6.92 \\
89.85^{\mathrm{b}} \pm 6.81\end{array}$ & $\begin{array}{l}88.56 \pm 8.89 \\
83.18 \pm 5.50 \\
85.87 \pm 6.71 \\
85.87^{\mathrm{b}} \pm 7.03\end{array}$ & $\begin{array}{l}100.43^{A} \pm 4.72 \\
86.57^{B} \pm 7.71 \\
87.66^{B} \pm 10.96\end{array}$ \\
\hline Glucose ( mg/dl) & $\begin{array}{l}35 \\
70 \\
105 \\
\text { Overall mean }\end{array}$ & $\begin{array}{c}118.17 \pm 2.88 \\
103.09 \pm 20.84 \\
88.77 \pm 6.16 \\
103.34^{\mathrm{b}} \pm 9.96\end{array}$ & $\begin{array}{r}118.52 \pm 9.33 \\
151.08 \pm 16.92 \\
114.27 \pm 7.61 \\
127.96= \pm 11.29\end{array}$ & $\begin{array}{c}153.32 \pm 37.03 \\
121.22 \pm 6.35 \\
137.27 \pm 15.51 \\
137.27 \mathrm{a} \pm 19.63\end{array}$ & $\begin{array}{l}130.00^{A} \pm 16.41 \\
125.13^{A} \pm 14.70 \\
113.44^{\mathrm{B}} \pm 9.76\end{array}$ \\
\hline
\end{tabular}


Talha, M. H. et al.

Table 5: (Continued).

\begin{tabular}{|c|c|c|c|c|c|}
\hline & & & Treatments & & \\
\hline Blood components & Age of lamb (days) & R1 & R2 & R3 & Overall mean \\
\hline Urea $(\mathrm{mg} / \mathrm{dl})$ & 35 & $15.67 \pm 0.91$ & $12.13 \pm 1.66$ & $11.29 \pm 1.42$ & $13.03^{B} \pm 1.33$ \\
\hline & 70 & $14.43 \pm 2.13$ & $13.28 \pm 2.61$ & $15.06 \pm 2.52$ & $14.26^{B} \pm 2.42$ \\
\hline & 105 & $29.07 \pm 4.92$ & $23.32 \pm 1.97$ & $13.18 \pm 1.61$ & $21.86^{A} \pm 2.84$ \\
\hline & Overall mean & $19.73^{a} \pm 2.65$ & $16.25^{\mathrm{ab}} \pm 2.08$ & $13.18^{b} \pm 1.85$ & \\
\hline Creatinine (mg/dl) & 35 & $0.68 \pm 0.20$ & $0.93 \pm 0.18$ & $1.74 \pm 0.13$ & $1.12^{A} \pm 0.17$ \\
\hline & 70 & $1.47 \pm 0.23$ & $1.72 \pm 0.10$ & $1.00 \pm 0.09$ & $1.40^{A} \pm 0.14$ \\
\hline & 105 & $1.30 \pm 0.10$ & $1.12 \pm 0.25$ & $1.37 \pm 0.40$ & $1.26^{\mathrm{A}} \pm 0.25$ \\
\hline & Overall mean & $1.15^{\mathrm{a} \pm 0.18}$ & $1.26^{a} \pm 0.18$ & $1.37^{a} \pm 0.21$ & \\
\hline Minerals & & & & & \\
\hline Zinc $(\mu \mathrm{g} / \mathrm{dl})$ & 35 & $472.73 \pm 32.58$ & $527.88 \pm 14.57$ & $558.18 \pm 13.26$ & $519.60^{A} \pm 20.14$ \\
\hline & 70 & $564.55 \pm 4.18$ & $566.06 \pm 16.80$ & $571.21 \pm 7.89$ & $567.27^{\mathrm{B}} \pm 9.96$ \\
\hline & 105 & $568.79 \pm 9.58$ & $546.97 \pm 3.33$ & $543.33 \pm 14.73$ & $553.03^{B} \pm 9.21$ \\
\hline & Overall mean & $535.35^{b} \pm 15.45$ & $546.97^{\mathrm{ab}} \pm 11.57$ & $557.57^{a} \pm 11.96$ & \\
\hline $\mathrm{Fe}(\mu \mathrm{g} / \mathrm{dl})$ & 35 & $942.31 \pm 411.29$ & $1242.73 \pm 572.98$ & $1015.38 \pm 494.50$ & $1066.81^{\mathrm{AB}} \pm 492.92$ \\
\hline & 70 & $1582.90 \pm 117.79$ & $1783.76 \pm 557.39$ & $1524.81 \pm 41.50$ & $1630.49^{B} \pm 238.89$ \\
\hline & 105 & $149.57 \pm 37.62$ & $438.46 \pm 227.25$ & $1270.09 \pm 265.69$ & $619.38^{A} \pm 176.85$ \\
\hline & Overall mean & $891.59^{b} \pm 188.90$ & $1154.98^{\mathrm{a}} \pm 452.54$ & $1270.09^{a} \pm 267.23$ & \\
\hline
\end{tabular}

$A, B$ : Values in the same column within each trait not sharing the superscript significantly differed $(P<0.05)$.

$a, b$, : Values in the same row not sharing the superscript significantly differed $(P<0.05)$. 